\title{
STATELESSNESS AS A PRODUCT OF SLIPPERY STATECRAFT: A GLOBAL GOVERNANCE VIEW OF CURRENT CAUSES, ACTORS AND DEBATES
}

\author{
AlLison J PETROZZIELLO*
}

\begin{abstract}
Statelessness has been described as the result of unintentional gaps between citizenship policies excluding individuals who move, form relationships and reproduce across international borders. But what if the rise in statelessness is not a technicality, but a strategy of slippery statecraft meant to design the citizenry a given state is willing to protect? This paper places statelessness within the context of neoliberal globalisation and international migration and provides a critical global governance view of contemporary causes of statelessness, key actors working on it and their framing of the issue within global governance frameworks. I argue that the dominant framing of statelessness as a technical issue obviates the politics behind statelessness as slippery statecraft, leading proposed solutions to fall short. Critical research may help advocates make the case for inclusion, appealing to broader state interests and networks, without abandoning attendant human rights obligations.
\end{abstract}

\section{TABLE OF CONTENTS}

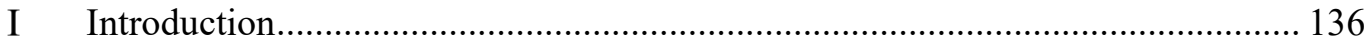

II A Brief History of Statelessness in Global Governance ..................................... 138

III Contemporary Causes of Statelessness ............................................................... 140

IV Global Governance Actors Concerned with Statelessness ……........................... 145

V UNHCR's Technical Approach to Ending Statelessness ...................................... 145

VI Institute on Statelessness and Inclusion's Human Rights-Based Approach .......... 148

VII Depoliticising Statelessness to Integrate It in Global Governance Frameworks .. 149

VIII Concluding Remarks: Seeing the state in Statelessness and New Ways of Seeing

\section{INTRODUCTION}

With unprecedented numbers of people on the move, stateless populations are cropping up in new places and for reasons other than displacement by conflict or state succession. International labour migration and attempts to manage it are creating what Rhoda Howard-Hassmann and Margaret Walton-Roberts have called a "slippery slope of citizenship" along which migrants and their children may find themselves manufactured as the 'citizen's Other' ${ }^{2}$ — not only noncitizens, but stateless.

* Allison J Petrozziello is a feminist migration researcher and human rights advocate, currently pursuing a PhD in Global Governance at Wilfrid Laurier University/Balsillie School of International Affairs in Canada, where she is affiliated with the International Migration Research Centre.

1 Rhoda E Howard-Hassmann and Margaret Walton-Roberts, The Human Right to Citizenship: A Slippery Concept (University of Pennsylvania Press 2015) 5.

2 Audrey Macklin, 'Who is the Citizen's Other? Considering the Heft of Citizenship' (2007) 8(2) Theoretical Inquiries in Law 333. 
Who might find themselves where along this slippery slope? At the top stand the lucky holders of hard citizenship rights in wealthy, democratic countries. ${ }^{3}$ Moving down the gradient we find people on the move who are categorised, documented, sorted and legally produced in a variety of ways: ${ }^{4}$ documented and undocumented migrants, recognised and unrecognised refugees, people who have been trafficked and smuggled, all of whom experience degrees of precarity whether in wealthy or less wealthy countries. ${ }^{5}$ Also on slippery footing we find: people holding precarious status forms, such as temporary work permits or temporary protection; those whose citizenship in poverty-stricken countries affords them little in the way of rights; and social groups whose citizenship is mediated through discriminatory policies and practices - women, ethnic minorities, racialised people, children and persons of minority sexual orientation. ${ }^{6}$ At the bottom of the slope stand the stateless, who are not recognised as citizens by any state but manage to carve out an existence for themselves nonetheless.

An estimated ten to fifteen million people have been made stateless. ${ }^{7}$ Their condition is often considered as a (hu)man-made problem, occurring as a result of unintentional gaps between citizenship policies excluding individuals who move, form relationships and reproduce across international borders. But what if the production of statelessness is not a technicality, but a slippery strategy that some states use to design the citizenry that they have the political will to protect?

This paper provides a critical global governance view of contemporary causes of statelessness, actors working on it and their framing of the issue. A global governance perspective brings into view a panoply of actors operating at levels of governance above and below the state — stateless individuals, an epistemic community convened by a think tank, transnational advocacy networks, UN agencies and campaigns, human rights activists and non-governmental organisations ('NGOs') - who come together in a variety of venues to identify solutions for global problems where state action has been found wanting. Mainstream approaches to the study and practice of global governance are often depoliticised and technocratic in nature, focusing on the creation of a policy framework to coordinate action on problems that cross borders. ${ }^{8}$ This can be seen in much scholarship and policy work on statelessness, which tend to focus on smoothing out the relationship between individuals and sovereign states rather than analysing exclusionary citizenship as part of the global state system. ${ }^{9}$ Critical scholarship on global governance, by contrast, aims to identify sources of conflict and contradiction, opening up space for reconsidering and potentially transforming the prevailing order.

3 Ayelet Shachar, The Birthright Lottery: Citizenship and Global Inequality (Harvard University Press 2009).

4 Nicholas De Genova, 'Migrant "Illegality" and Deportability in Everyday Life' [2002] Annual Review of Anthropology 419; Heather Johnson, Borders, Asylum and Global NonCitizenship: The Other Side of the Fence (Cambridge University Press 2014).

5 Howard-Hassmann and Walton-Roberts (n 1) 5-6.

6 ibid.

7 United Nations High Commissioner for Refugees, Global Trends: Forced Displacement in 2016 (Report, 19 June 2017) 2; Institute on Statelessness and Inclusion, The World's Stateless (Wolf Legal Publishers 2014) 11.

8 Shirin M Rai and Georgina Waylen, Global Governance: Feminist Perspectives (Palgrave Macmillan 2008) 2.

9 Shachar (n 3) 5; Bridget Anderson, Us and Them? The Dangerous Politics of Immigration Control (Oxford University Press 2013) 94. 
To that end, the paper situates the issue of statelessness, which historically has been associated with interwar and post-World War II ('WWII') refugees, ${ }^{10}$ within the contemporary context of neoliberal globalisation and international migration. It begins with a brief history of statelessness in global governance, before proceeding to contrast the slippery statecraft involved in the contemporary causes of statelessness with the apparent depoliticisation of the issue as it is integrated into global governance frameworks. Regarding the contemporary causes of statelessness, the paper asks: what is the relationship between neoliberal globalisation, migration management and statelessness, if any? What forms of discrimination and denationalisation are states employing, and to what end? Second, the paper looks at key international organisations and non-state actors which are considering statelessness, such as the United Nations High Commissioner for Refugees ('UNHCR') and the emergent epistemic community convened by the Institute on Statelessness and Inclusion ('ISI'), and how each understands the problem. The final section provides examples of the depoliticised, technical language used to incorporate statelessness into the Sustainable Development Agenda ('SDA'), New York Declaration for Refugees and Migrants ('New York Declaration'), the Global Compact for Safe, Orderly and Regular Migration ('Global Compact on Migration') and the Global Compact on Refugees.

Only recently has statelessness been rediscovered as an international concern. The numbers of persons without state recognition suggest that the issue will continue to present challenges to global governance, not least because it reveals inherent contradictions in the international system of states and the human rights framework. I argue that the dominant framing of the problem as a technical, legal matter, led by UNHCR, obviates the politics behind statelessness as slippery statecraft. ${ }^{11}$ This may lead proposed solutions to fall short of their mark and risks aggravating rights violations. Critical research on the causes of statelessness may help advocates figure out how to make the case for inclusion, appealing to broader state interests and networks, without abandoning attendant human rights obligations. In the concluding remarks, I argue for bringing the politics back in so we can see the state in statelessness and then briefly consider new frames for delivering justice and belonging to the stateless.

\section{A Brief History of StATELESSNESS IN GLOBAL GOVERnANCE}

To understand statelessness, one starting point is its conceptual opposite: citizenship. Sociologically, citizenship is understood as a set of rights and entitlements that an individual may access through state protection; legally and politically, it refers to formal recognition by a state, or status. ${ }^{12}$ The latter notion of citizenship as status 'originated in the West and spread across the globe with the rise of the international system of states and the spread of colonialism'.13 Recognition of citizenship was part of the original project of the Westphalian

10 Hannah Arendt, The Origins of Totalitarianism (Harcourt Brace Jovanovich 1973) 344.

11 Kim Rygiel and Margaret Walton-Roberts, 'Multiple Citizenships and Slippery Statecraft' in Rhoda E Howard-Hassmann and Margaret Walton-Roberts (eds), The Human Right to Citizenship: A Slippery Concept (University of Pennsylvania Press 2015) 210.

12 Audrey Macklin, 'Who is the Citizen's Other? Considering the Heft of Citizenship' (2007) 8(2) Theoretical Inquiries in Law 334.

13 Kristy Belton, Statelessness in the Caribbean: The Paradox of Belonging in the Postnational World (University of Pennsylvania Press 2017) 160. 
political imaginary, ${ }^{14}$ wherein international space was carved up into states, each of which was to hold exclusive sovereignty over its territory and to enter into a social contract with its people. Though never a fully realised goal, determining who was subject to that social contract - that is, who are the citizens of a given state - was and continues to be considered a matter of national sovereignty in its classic sense. ${ }^{15}$ Modern social contract theory held that citizen subjects would recognise the legitimacy of the sovereign power in exchange for protection of their rights. While all of these ideas - territory, citizenship, belonging, sovereignty, subjectivity and social contract - were, and to some extent continue to be, highly contested, the problematic tethering of citizenship to rights protection and fulfilment persists to this day. ${ }^{16}$

Questions of citizenship entered the international realm in the interwar years, when many World War I survivors found themselves as stateless refugees, as Hannah Arendt explains in her classic work, The Origins of Totalitarianism. ${ }^{17}$ In the lead-up to WWII, stripping of citizenship, or de-nationalisation, preceded unspeakable human rights violations against Jewish people and other minority groups. ${ }^{18}$ Preventing another such atrocity was a central concern when laying the foundations of the liberal international order. The right to a nationality was recognised as a human right in the Universal Declaration of Human Rights, as was the right to leave one's country of origin; at the same time, sovereign states were neither required to grant nationality nor entry. ${ }^{19}$ After the 1951 adoption of the Convention Relating to the Status of Refugees ('Refugee Convention'), 20 the United Nations adopted two conventions on statelessness as part of its international project of delimiting political power and extending liberal democratic concerns to the international sphere. ${ }^{21}$ The 1954 Convention Relating to the Status of Stateless Persons was designed to ensure a minimum set of rights and treatment of stateless people, ${ }^{22}$ while the 1961 Convention on the Reduction of Statelessness ('1961 Convention') called for safeguards to prevent statelessness and reduce it over time. ${ }^{23}$

In addition to the aftermath of the World Wars, the twentieth century was marked by imperial breakdown, decolonisation and subsequent processes of state formation. As newly forming nation-states imposed their political imaginary on bounded territories, minority groups were often excluded from the new polity, leaving them effectively stateless, as is the case for the Palestinians vis-à-vis Israel

14 Nancy Fraser, 'Who Counts? Dilemmas of Justice in a Postwestphalian World' (2010) 41 Antipode 281, 282.

15 Anderson (n 9) 28.

16 ibid.

17 Arendt (n 13) 344.

18 ibid.

19 The Universal Declaration of Human Rights, Ga Res 217A (III), UN Doc A/810 (10 December 1948) arts 13(2), 15.

20 Convention Relating to the Status of Refugees, opened for signature 28 July 1951, 189 UNTS 137 (entered into force 22 April 1954).

21 David Held 'Law of States, Law of Peoples: Three Models of Sovereignty' 8(1) Legal Theory 1,5 .

22 Convention Relating to the Status of Stateless Persons, opened for signature 28 September 1954, 360 UNTS 117 (entered into force 6 June 1960); United Nations High Commissioner for Refugees 'UN Conventions on Statelessness' <https://www.unhcr.org/un-conventionson-statelessness.html>.

23 Convention on the Reduction of Statelessness, opened for signature 30 August 1961, 989 UNTS 175 (entered into force 13 December 1975) ('1961 Convention'). 
or the Rohingya vis-à-vis Myanmar (Burma). The 1961 Convention set out safeguards to prevent statelessness due to state succession, but also recognised limited situations in which states can deprive a person of his or her nationality, even if this would leave them stateless. ${ }^{24}$

This brief overview traces how statelessness emerged as an international concern within a particular set of circumstances, which continue to influence its conceptualisation today. In their recent volume, Understanding Statelessness, Tendayi Bloom, Katherine Tonkiss, and Phillip Cole identify three key moments in thinking about statelessness: 1) post-WWII when statelessness was considered exception; 2) the beginning of the twenty-first century when statelessness became a phenomenon; and 3) 2013 onward with statelessness seen as endemic or even symptomatic of modernity. ${ }^{25}$ Despite having moved on from the moment of exception, statelessness is most often associated with interstate conflict, decolonisation and state formation, forced displacement and the refugee cycle. While these crisis-driven causes are still at work in the world today, exclusion from citizenship is occurring gradually through institutional means as well. The next section considers some of the contemporary factors which are fuelling the phenomenon of statelessness in the early twenty-first century.

\section{CONTEMPORARY CAUSES OF STATELESSNESS}

Contemporary causes of statelessness must be understood within the context of neoliberal globalisation and the politically charged issues of international labour migration, securitisation and persistent discrimination. The messy politics of global migration governance stand in sharp contrast to the depoliticised language of birth registration and child protection measures to combat statelessness, which are discussed later in the paper.

Recent literature on (non)citizenship offers a lens through which to begin to identify risk factors for statelessness. ${ }^{26}$ Many of these derive from states' manipulation of citizenship as a means of governing human mobility. By parsing out factors related to identity, security, mobility, and reorganising them into a variety of new status forms, citizenship is made precarious for noncitizens and completely out of reach for the stateless. While stateless people share a similar lot with other noncitizens - such as irregular migrants, asylum seekers and their children - their situation is also particular insofar as recognition by a state, any state, continues to be the sine qua non for securing access to the full range of one's human rights. Precarity is a permanent condition for the stateless, and they may even be penalised for 'unlawful' presence by the very state that made them so in the first place by denying citizenship. ${ }^{27}$

241961 Convention (n 23) arts 8(2)-(3), 10.

25 Tendayi Bloom, Katherine Tonkiss, and Phillip Cole (eds), Understanding Statelessness (Routledge 2017) 4.

26 See, eg, Katherine Tonkiss and Tendayi Bloom, 'Theorising Noncitizenship: Concepts, Debates and Challenges' (2015) 19(8) Citizenship Studies 837; David Owen 'Republicanism and the Constitution of Migrant Statuses' (2014) 17(1) Critical Review of International Social and Political Philosophy 90; Marit Hovdal-Moan 'Unequal Residence Statuses and the Ideal of Non-Domination' (2014) 17(1) Critical Review of International Social and Political Philosophy 70.

27 Belton (n 13) 11. 
Such manoeuvres are what Kim Rygiel and Margaret Walton-Roberts call 'slippery statecraft': governments' strategic use of citizenship to manage populations in order to position themselves competitively in the global economy.

We use the term 'slippery statecraft' to draw attention to this process by which states use citizenship to open membership to some 'desirable' populations, while simultaneously employing securitisation to 'shed' certain other populations. Rather than seeing these trends as contradictory, the term 'slipperiness' draws attention to the way these competing economic and security logics work in tandem as part of the new dynamics of neoliberal statecraft, where the state is viewed not as a unified territorially bounded whole but as an assemblage of territorial and nonterritorial practices that operate simultaneously across various geopolitical scales. ${ }^{28}$

What does globalisation have to do with this state of affairs? Not only has neoliberal globalisation compressed time and space; increased flows of information, people, goods, capital; and deterritorialised social, economic and political life, ${ }^{29}$ so too has it set about reconfiguring relationships between the governing and the governed, sovereignty and territoriality. In the global governance literature, the 1990s is seen as the decade when neoliberalism spread, not only as an economic doctrine upholding the primacy of the market and limiting state power, but as an ideology and technology of governance in which governing activities are cast as non-political problems in need of technical solutions. ${ }^{30}$

In Neoliberalism as Exception: Mutations in Citizenship and Sovereignty, Aihwa Ong describes the ways in which neoliberal logic is infiltrating technologies of population governance: government provision and guarantee of rights for citizen insiders depends on the exclusion of noncitizen outsiders, even if they physically reside in a territory under state control. ${ }^{31}$ This manoeuvre is what she calls the neoliberal exception. ${ }^{32}$ Here Ong draws on Italian philosopher Giorgio Agamben's variation of Carl Schmitt's political exception. ${ }^{33}$ Instead of regarding the political exception as a means of distinguishing between friend and foe during conflict, Agamben sees the exception as a fundamental principle in the exercise of sovereignty, ${ }^{34}$ enabling the state to strip noncitizens down to a condition he calls 'bare life' ${ }^{35}$ A sovereign state determines who belongs to its juridical order, and denies state protection to all those cast outside its purview, creating important dilemmas as to who counts as a subject of justice ${ }^{36}$ - a point to which I return in the concluding remarks.

As production processes have become dispersed and management concentrated, globalisation has increased demand for labour mobility. Yet it is widely acknowledged that liberalisation of the mobility of capital and goods has not been accompanied by the free movement of labour. Migration policies the

28 Rygiel and Walton-Roberts (n 11) 211.

29 Jan A Scholte, Globalization: A Critical Introduction (Palgrave 2005) 8.

30 Philip Cerny, Rethinking World Politics: A Theory of Transnational Neopluralism (Oxford University Press 2010); Robert W Cox, Approaches to World Order (Cambridge University Press 1996); Susan Strange, The Retreat of the State (Cambridge University Press 1996).

31 Aihwa Ong, Neoliberalism as Exception: Mutations in Citizenship and Sovereignty (Duke University Press 2006).

32 ibid 19.

33 ibid 5.

34 Giorgio Agamben, State of Exception (University of Chicago Press 2005).

35 Giorgio Agamben, Homo Sacer: Sovereign Power and Bare Life (Stanford University Press 1998).

36 Fraser (n 14) 281. 
world over seek to fast track the movement of investors and high-skilled workers while clamping down on the mobility of the lower-skilled. ${ }^{37}$ Like globalisation itself, this has a temporal dimension - opening a path to permanent residency for the former while allotting temporary status to the latter - and also a spatial dimension, as new territories and spaces are put to work in the technology of bordering and defining political belonging. Thus migration management has become a governance tool for exercising the neoliberal exception, "pry[ing] open the seam between sovereignty and citizenship, generating successive degrees of insecurity for low-skilled citizens and migrants who will have to look beyond the state for the safeguarding of their rights'. ${ }^{38}$ Critical migration scholars have pointed out the ways in which citizenship policy functions as a hinge to maintain a bifurcation between skilled migrant workers (who are afforded some access to social rights and entitlements and often a path to citizenship) and those deemed less skilled (who are given little to no access to rights or citizenship). ${ }^{39}$ The stratification of rights and entitlements for those considered more or less desirable to the neoliberal state would appear to be by design. Citizenship rights, like sovereignty, were premised on boundedness; ${ }^{40}$ so, the presence of noncitizens is a challenge to states. One of the technologies states are using to govern noncitizens is the proliferation of semi-legitimate or ambiguous status forms.

Receiving states, through institutional and administrative governance practices, are creating new categories or 'quasi-forms of political recognition'. ${ }^{41}$ These ad hoc statuses, such as temporary humanitarian protected status or temporary guest worker, are a stop-gap measure that some governments use to bring displaced people into the documentary power of the state without granting full refugee status for all, in the case of the former, and a way to meet actual demand for migrant labour without providing a path to permanent residency, in the latter. While politically expedient, such measures often place ad hoc status holders in a prolonged period of structural ambiguity. ${ }^{42}$ This raises their risk of sliding further down the slippery slope of citizenship, as delays and non-renewal of status or identity documents prolong and compound precarity over time. When women with such circumscribed status give birth outside their country of origin, host states may transfer this ambiguous status to their children, leading to an intergenerational risk of statelessness. ${ }^{43}$ Creation of in-between statuses and precarious citizenship is not an accident, argues Noora Lori, but 'a strategic government response to avoid resolving dilemmas about citizenship (especially questions about the incorporation of minorities, refugees, or labour migrants) by postponing those

37 Anne McNevin, Contesting Citizenship: Irregular Migrants and New Frontiers of the Political (Columbia University Press 2011) 2; Tanya Basok and Nicola Piper, 'Management versus Rights: Women's Migration and Global Governance in Latin America and the Caribbean' (2012) 18(2) Feminist Economics 35, 38.

38 Ong (n 31) 19.

39 Anderson (n 9) 71-2; Shachar (n 3) 43; Nicola Piper, New Perspectives on Gender and Migration: Livelihood, Rights and Entitlements (Routledge 2013) 11.

40 Anderson (n 9) 71-2; Dimitris Papadopoulos and Vassilis S Tsianos, 'After Citizenship: Autonomy of Migration, Organisational Ontology and Mobile Commons’ (2013) 17(2) Citizenship Studies 178, 183.

41 McNevin, 'Contesting Citizenship' (n 37) 9.

42 Suzan Ilcan, Kim Rygiel and Feyzi Baban, 'The Ambiguous Architecture of Precarity: Temporary Protection, Everyday Living, and Migrant Journeys of Syrian Refugees' (2018) 4(1/2) International Journal of Migration and Border Studies 51, 54-7.

43 Allison J Petrozziello, '(Re)Producing Statelessness via Indirect Gender Discrimination: Descendants of Haitian Migrants in the Dominican Republic' (2019) 57(1) International Migration 213, 222. 
decisions, perhaps indefinitely'. ${ }^{44}$ In line with the neoliberal logic of exception, assigning ambiguous and temporary legal status gives governments the flexibility to manage labour migration to compete in the global economy, while restricting the terms of the social contract.

Following Rygiel and Walton-Roberts' idea of slippery statecraft, we might also turn to the security logic which operates in tandem with this neoliberal economic logic. ${ }^{45}$ States' capacity to provide security is part and parcel of the sovereign social contract, which again hinges on the definition of who is a citizen. Governments around the world have come under increasing pressure in the post9/11 era to document their populations and strengthen identity management systems, ostensibly as a means of distinguishing between friend and foe. ${ }^{46}$ Following a similar logic of political exception as it applies to state processes of securitisation, 'the citizen that needs to be secured is not the same as the secured citizen'. ${ }^{47}$

Contributors to Peter Nyers' volume Securitizations of Citizenship use the Foucauldian concept of biopolitics to examine the reconfiguring of relationships between security, territory, population and citizenship. ${ }^{48}$ Biometric technologies - finger printing, retinal scans, facial recognition and the like - are a pervasive means of identity verification employed by developed and developing states alike, through generous financing by the World Bank and others. ${ }^{49}$ Benjamin Muller sees the shift toward citizenship as identity management as both politicising and depoliticising. ${ }^{50}$ On one hand, the bureaucratised realm of identity management would seem to limit possibilities for discrimination, purging out the 'ugly politics of us and them, friends and enemies, inclusion and exclusion', 51 thus depoliticising questions of identity and security. However, Benjamin Muller, ${ }^{52}$ Bronwen Manby and others have shown that in practice biometric technologies simply conceal ongoing racial/ethnic profiling, suggesting that the usual exclusionary politics persist. ${ }^{53}$ Biopolitics redraws borders on bodies of populations subject to surveillance, playing a central role in globalising regimes of population management. ${ }^{54}$ When biometrics combine with record-breaking levels of displacement, irregular migration and exclusionary othering, people who do not fit into pre-conceived categories slide further down that slippery slope toward statelessness - which, again, is not accidental, but part of neoliberal statecraft.

Just as racial and ethnic discrimination feature in processes of state formation, so do they persist in projects of state modernisation, generating a risk of statelessness in situ. In her book on statelessness among persons of Haitian descent

44 Noora A Lori, 'Statelessness, "In-Between" Statuses, and Precarious Citizenship' in Ayelet Shachar et al (eds), The Oxford Handbook of Citizenship (Oxford University Press 2017), 744.

45 Rygiel and Walton-Roberts (n 11) 211.

46 ibid.

47 Peter Nyers (ed), Securitizations of citizenship (Routledge 2009) 3.

48 ibid

49 Lori (n 44) 749-50.

50 Benjamin J Muller, '(Dis)Qualified Bodies: Securitization, Citizenship and "Identity Management"' in Peter Nyers (ed) Securitizations of Citizenship (Routledge 2009) 78.

51 ibid.

52 ibid.

53 Bronwen Manby, Citizenship in Africa: The Law of Belonging (Hart 2018).

54 Kim Rygiel, Globalizing Citizenship (University of British Columbia Press 2010). 
in The Bahamas and the Dominican Republic, Kristy Belton argues that most of the world's stateless have not migrated at all, but rather have been displaced in situ through deprivation and denial of citizenship. ${ }^{55}$ Their plight is similar to that of refugees and other forced migrants, except they have not and cannot leave the place where they were born. ${ }^{56}$ Such discrimination is enacted through allegedly neutral laws and banal bureaucratic procedures, ${ }^{57}$ such as modernisation of identity cards ${ }^{58}$, yet the outcomes are highly discriminatory. Racialised 'Others' are framed as not belonging to the state, and the social contract rescinded. Thus, democracies are engaged in the production of statelessness through legal, bureaucratic and political means. ${ }^{59}$

A final contemporary risk factor for statelessness is gender discrimination as it pertains to the right to a nationality for migrant and refugee women's children. Birthright citizenship or jus soli provisions have been rolled back in many different countries in recent decades: 60 Australia (1986), India (1987), South Africa (1995), New Zealand (2006), UK (1981), Belgium (1992), France (1993 and 1998), Germany (2000), Ireland (2004) and Dominican Republic (2010). 61 Where jus sanguinis policies limit women's ability to pass on citizenship, their children also face a risk of statelessness. ${ }^{62}$ Gender discriminatory dynamics also play out in the political, bureaucratic and institutional arenas, limiting women's ability to secure a positive migration status, identity documents and consequently, birth registration for their children. ${ }^{63}$ Nonetheless, recent literature on statelessness has yet to extend its analysis beyond the formal, legal scope of gender discrimination in nationality and other laws. ${ }^{64}$ As I argue elsewhere, ${ }^{65}$ the links between gender and statelessness are indeed legal — but also historical, structural, political and procedural. A full feminist accounting of the ways in which patriarchal structures contribute to the creation of statelessness, as Deirdre Brennan calls for, is much needed. ${ }^{66}$

55 Belton (n 13) 13.

56 ibid.

57 ibid 5.

58 Allison J Petrozziello, Género y el riesgo de apatridia para la población de ascendencia haitiana en los bateyes de República Dominicana [Gender and the Risk of Statelessness for the Population of Haitian Descent in the Bateys of the Dominican Republic] (Centro para la Observación Migratoria y el Desarrollo Social en el Caribe, $2^{\text {nd }}$ ed, 2017).

59 Belton (n 13) 15; Lori (n 44).

60 Aoileann Ní Mhurchú, Ambiguous Citizenship in an Age of Global Migration (Edinburgh University Press 2014) 5.

61 See generally Australian Citizenship (Amendment) Act 1986 (Cth); Citizenship Act 1955 (India) No 57 of 1955, as amended by Act No 51 of 1987; South African Citizenship Act 1955 (South Africa); Citizenship Act 1977 (NZ) as amended by the Citizenship (Amendment) Act 2005 (NZ); British Nationality Act 1981 (UK) 29 Eliz, c 61; Code of Belgian Nationality 1984 (Belgium) as amended by the Law of 13 June 1991; loi méhaignerie (France) JO, 1993; loi Guigou (France) JO, 1998; Staatsangehörigkeitsgesetz [Nationality Law] (Germany) 22 July 1913, BGBI III as amended in 2000; Irish Nationality and Citizenship Act 2004 (Ireland) No 38 of 2004; Jillian Blake, 'Race-Based Statelessness in the Dominican Republic' in Tendayi Bloom, Katherine Tonkiss and Phillip Cole (eds), Understanding Statelessness (Routledge 2017) 107.

62 Howard-Hassmann and Walton-Roberts (n 1) 7-8.

63 Petrozziello, Género y el riesgo de apatridia (n 58).

64 ibid.

65 ibid.

66 Deirdre Brennan, 'Statelessness and the Feminist Toolbox: Another Man-Made Problem with a Feminist Solution?' (2019) Tilburg Law Review (forthcoming). 
Having considered some of the slippery statecraft involved in governing international migration and identity management, coupled with persistent forms of discrimination, let us now consider who is actually working on statelessness and how they frame the issue.

\section{Global Governance Actors CONCERnED With StATELESSNESS}

Until recently, statelessness as a stand-alone issue had received little attention from human rights, humanitarian, academic, or policy making circles. ${ }^{67}$ This has shifted in the years since 2013 as a variety of intergovernmental and non-state actors have generated an upsurge in global attention to the right to a nationality within the context of displacement and international migration, ${ }^{68}$ which together are commonly referred to as mixed migration movements or flows. In 2014, UNHCR launched a 10-year campaign to eradicate statelessness and held the first Global Forum on Statelessness. ${ }^{69}$ The ISI was founded that year, marking the emergence of a global epistemic community dedicated to advancing research, training and advocacy on the issue. Both have been galvanising energy and bringing together state and non-state actors around the world, leading to the formation of regional advocacy networks, such as the European Network on Statelessness ('ENS') and the Americas Network on Statelessness. UNHCR and ISI were also among the founding members of the Global Campaign for Equal Nationality Rights, which is coordinated by the Women's Refugee Commission. ${ }^{70}$ This section considers these global governance actors in turn, taking note of their working strategies and understanding of the problem of statelessness. While the upsurge in efforts to address statelessness is promising, the problem-solving approach to smoothing out the relationship between individuals and sovereign states does little to address the problematic use of exclusionary citizenship to manage mobility.

\section{UNHCR’s TECHNICAL APPROACH TO ENDING STATELESSNESS}

UNHCR's work on statelessness began with refugees in the post-WWII era. Following the adoption of the 1954 and 1961 Conventions, it was to assist in the examination and presentation of claims on behalf of stateless refugees. ${ }^{71}$ However, it wasn't until the mid-1990s that the agency was granted an international mandate to prevent and reduce statelessness. ${ }^{72}$ In 2006 the mandate expanded to include the identification and protection of stateless persons, covering all situations of

67 Bloom, Tonkiss and Cole (n 25) 4-5.

68 Some regional intergovernmental processes and organisations, such as the Organization of American States ('OAS') and the European Union ('EU') have begun to address statelessness as well. See Organization of American States, Prevention and Reduction of Statelessness and Protection of Stateless Persons in the Americas, AG/RES.2826 (XLIV-O/14) (4 June 2014); Brazil Declaration and Plan of Action, signed 3 December 2014. See also Council of the European Union, Conclusions of the Council and the Representatives of the Governments of the Member States on Statelessness (Conclusions, 4 December 2015).

69 United Nations High Commissioner for Refugees, Global Action Plan to End Statelessness: 2014-2024 (Report, November 2014) ('Global Action Plan').

70 Global Campaign for Equal Nationality Rights, 'About Us' $<$ https://equalnationalityrights.org/about-us> ('GCENR About Us').

71 United Nations High Commissioner for Refugees, UNHCR Action to Address Statelessness (Strategy Note, March 2010) 4.

72 See, eg. GA Res 49/169, UN Doc A/RES/49/169 (23 December 1994); GA Res 50/152, UN Doc A/RES/50/152 (9 February 1996). 
statelessness, not only refugees. ${ }^{73}$ UNHCR began to intensify efforts toward this end as of 2008 and to triple funding allocated to the issue between 2009 and 2013, from 12 to 36 million. ${ }^{74}$ In October 2013, the UN High Commissioner for Refugees, António Guterres, who is now serving as the UN Secretary-General, called for the 'total commitment of the international community to end statelessness'. ${ }^{75}$ To operationalise this commitment, UNHCR consulted with states, civil society and international organisations to develop the Global Action Plan to End Statelessness: 2014-2024 ('Global Action Plan'). ${ }^{76}$ With the endorsement of high-profile supporters, such as actress and special envoy Angelina Jolie and the collaboration of fashion company United Colors of Benetton, in November 2014 UNHCR launched the \#IBELONG Campaign. ${ }^{77}$ The stated intent of UNHCR's Global Action Plan is to 'bring an end to statelessness within 10 years by resolving existing situations and preventing the emergence of new cases of statelessness'. ${ }^{78}$

UNHCR's working strategies include collaborating with governments, civil society, other UN agencies and stakeholders to develop national action plans; providing technical advice and resources; promoting exchange of good practices; engaging the justice sector for strategic litigation; raising global awareness; and advocating for an end to statelessness. ${ }^{79}$ To bring such a disparate group of actors to the table, international organisations, such as the UNHCR, must construct a federating discourse to build consensus. ${ }^{80}$ This entails discursively separating the issue at hand — statelessness — from the messy realm of politics, effectively depoliticising it.

This is why UNHCR frames the issue of statelessness in technical and legal terms, obviating the politics underlying states' (un)willingness to recognise or confer nationality. Taking the international system of states as a given, it sees statelessness as a 'glaring anomaly' and declares that with political will and lowcost reforms, states can resolve even large-scale situations. ${ }^{81}$ Emphasis is placed on adherence to international law and implementation of technical solutions, such as identification and birth registration. ${ }^{82}$ The stateless are cast as blameless, innocent and the problem entirely solvable, as the \#IBELONG Campaign website suggests: 'the irony is that these people find themselves stateless through no fault of their own - and in most cases their condition could be resolved through minor changes in existing laws'. ${ }^{83}$

73 GA Res 61/137, UN Doc A/RES/61/137 (19 December 2006).

74 United Nations High Commissioner for Refugees, 'Financials: Budget — 2013' (2014) $<$ http://reporting.unhcr.org/financial $>$.

75 Antonio Guterres, 'High Commissioner's Closing Remarks to the 64th Session of UNHCR's Executive Committee' (Speech, Palais des Nations, Geneva, 4 October 2013).

76 Global Action Plan (n 69).

77 Divers, 'UNHCR Launches 10-Year Global Campaign to End Statelessness' (United Nations High Commissioner for Refugees, 4 November 2014) $<$ https://www.unhcr.org/afr/news/latest/2014/11/545797f06/unhcr-launches-10-year-globalcampaign-end-statelessness.html $>$.

78 Global Action Plan (n 69) 4.

79 ibid 5.

80 Antoine Pécoud, Depoliticising Migration (Palgrave Macmillan 2014).

81 ibid 7.

82 Kelly Staples, 'Recognition, Nationality, and Statelessness: State-Based Challenges for UNHCR's Plan to End Statelessness' in Tendayi Bloom, Katherine Tonkiss and Phillip Cole (eds), Understanding Statelessness (Routledge 2017) 178.

83 United Nations High Commissioner for Refugees, 'What Does it Mean to Be Stateless?' $<$ https://www.unhcr.org/ibelong/what-does-it-mean-to-be-stateless/>. 
In line with the emphasis on innocence, the campaign has highlighted child statelessness (actions 2 and 7). ${ }^{84}$ A 2015 report entitled I am Here, I Belong: The Urgent Need to End Child Statelessness conveys a sense of urgency — 'with a stateless child being born somewhere in the world at least every 10 minutes, this is a problem that is growing. In countries hosting the 20 largest stateless populations, at least 70,000 stateless children are born each year'. ${ }^{85}$ It goes on to strategically link the issue to development goals, such as child vaccination, access to medical care and education and youth access to employment. ${ }^{86}$ The report appeals to moral arguments about children missing out on the experience of being a child, as well as the human right of every child to a nationality. ${ }^{87}$ Again, UNHCR insists that the problem is relatively easy to solve, preventable, straightforward, since the causes are simply discrimination, gaps in nationality laws and lack of birth registration. ${ }^{8}$ UNHCR has partnered with the United Nations Children's Fund ('UNICEF') to promote universal birth registration; the two agencies convene the global Coalition on Every Child's Right to a Nationality, comprised of international organisations, civil society organisations and legal clinics, which aims to 'develop, expand and strengthen international cooperation to raise awareness about and combat the hidden problem of child statelessness' ${ }^{89}$

As for the link with international migration, UNHCR carefully avoids the thorny issue of irregular migration and the risk of statelessness for children. Campaign materials recognise that most stateless people remain in the country of their birth, which can and does include children of people with precarious citizenship, such as the temporary status forms described above. However, the focus is quite narrow: campaign action 6 calls for granting protection status to the relatively small number of stateless persons who have migrated and facilitating their naturalisation. 90

The 2017 \#IBELONG Campaign report focuses on discrimination against minority groups. ${ }^{91}$ It points out that discrimination and lack of documentation can be both cause and consequence of statelessness: 'Lack of such documentary proof can result in a vicious circle, where authorities refuse to recognise an otherwise valid claim to nationality'. ${ }^{92}$ Recommended actions to remedy this situation, in line with actions 1, 2, 4, 7 and 8 of the Global Action Plan, are technical in nature (eg ensure universal birth registration; eliminate procedural and practical obstacles to the issuance of nationality documentation). ${ }^{93}$

Gender discrimination is framed in similarly technical terms (action 3). ${ }^{94}$ UNHCR sees its role as advocate and provider of technical advice as to how to

84 Global Action Plan (n 69) 9, 18.

85 United Nations High Commissioner for Refugees, I am Here, I Belong: The Urgent Need to End Child Statelessness (Report, November 2015) 1.

86 ibid 2.

87 ibid.

88 ibid.

89 United Nations High Commissioner for Refugees, 'IBELONG: Coalition on Every Child's Right to a Nationality' <http://www.unhcr.org/ibelong/unicef-unhcr-coalition-child-rightnationality/>.

90 Global Action Plan (n 69) 16.

91 United Nations High Commissioner for Refugees, 'This is our Home': Stateless Minorities and Their Search for Citizenship (Report, November 2017).

92 ibid 2.

93 Global Action Plan (n 69) 7, 9, 13, 18, 21.

94 ibid 12. 
remove gender discrimination from nationality laws, policies and procedures. ${ }^{95} \mathrm{It}$ is working with UN Women, UNICEF, Office of the United Nations High Commissioner for Human Rights ('OHCHR') and civil society members of the Global Campaign for Equal Nationality Rights to promote legislative and constitutional reform, engage in strategic litigation and build capacity of legal professionals and the justice sector. ${ }^{96}$ The Global Campaign for Equal Nationality Rights is comprised of local, regional and international NGOs, academics, civil society organisations, the aforementioned UN agencies and some likeminded governments. ${ }^{97}$ Launched in 2014, it mobilises action through national and global advocacy, research and knowledge sharing. ${ }^{98}$ The campaign highlights gender discrimination in nationality laws as one of the primary causes of statelessness, such as when children cannot acquire their parents' nationality, or when a woman loses her nationality upon marriage to a foreigner. ${ }^{99}$ Importantly, it also frames the issue as a violation of women's rights, a factor contributing to gender-based violence, a cause of psychological distress and a hindrance to the achievement of the Sustainable Development Goals ('SDGs'). ${ }^{100}$

\section{INSTITUTE ON STATELESSNESS AND INCLUSION’s HUMAN RIGHTS-BASED}

\section{APPROACH}

The emerging epistemic community convened by the ISI considers statelessness primarily from a lens of human rights. ${ }^{101}$ Building on the work of the former Statelessness Program at Tilburg University in the Netherlands, the ISI has brought together academics and practitioners working on statelessness around the world to strategically contribute to the emerging global movement. ${ }^{102}$ According to its website, the ISI's founders

felt that ongoing efforts to give stateless persons a greater voice and more agency to influence this growing movement could be further strengthened. They also noted the clear need for an organisation that could help to bridge the divide between academic research, policy development and practice; and that could, through engagement with the arts, raise the profile of and provoke thought on the issue among a wider audience. The founders also felt that there was a need for greater dialogue, partnership and cross-fertilisation between the field of statelessness and those focusing on other forms of disenfranchisement; and that work on statelessness must be multidisciplinary, though underpinned by the international human rights framework. ${ }^{103}$

In line with this vision, ISI's working strategies include: research and academic engagement; networking and partnerships; empowerment; advocacy; information

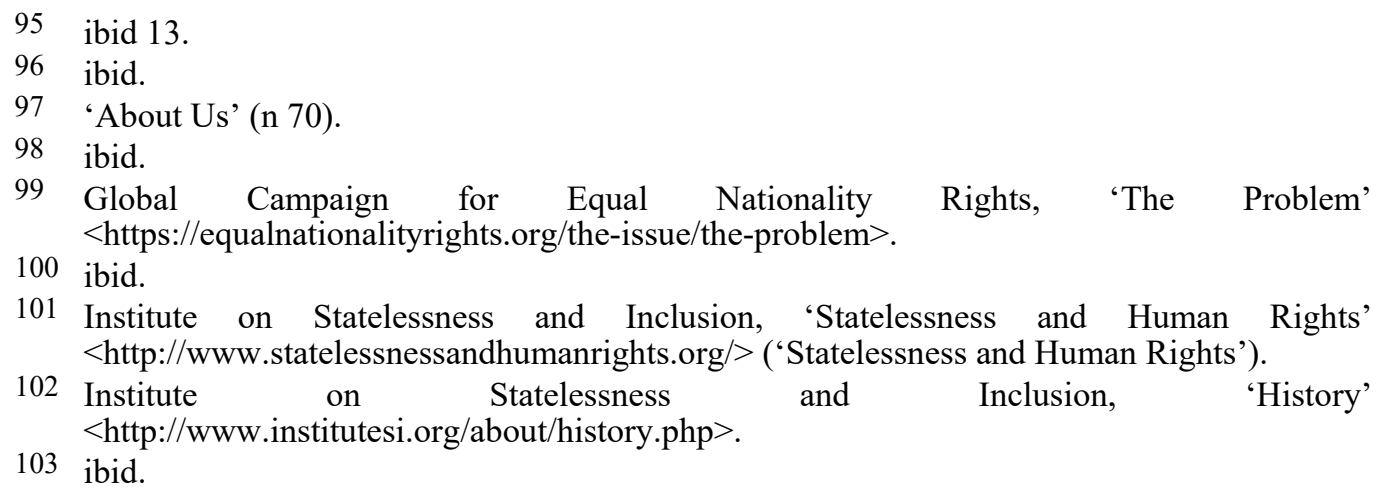


and awareness; training and capacity building. ${ }^{104}$ Given the framing of statelessness as a human rights issue, the ISI is making use of various human rights tools to redress it, including the Universal Periodic Review and review processes by the Committee on the Elimination of Discrimination against Women and the Committee on the Rights of the Child ('CRC'). ${ }^{105}$

Linking up with global attention to child statelessness, ISI dedicated its second flagship report to the issue. ${ }^{106}$ At the time of writing, they had prepared 12 different country submissions to the CRC and launched an online toolkit for civil society organisations on using the CRC to address the right to a nationality. ${ }^{107}$ The ISI also collaborates with a campaign by the ENS, entitled 'None of Europe's Children Should Be Stateless'. 108 The ISI sees the focus on child rights as strategic because the CRC is the most widely ratified international human rights treaty, and also because the right to nationality is an 'enabling right' that impacts children's enjoyment of all the other rights. 109

While emphasis continues to be on international human rights law and statelessness as a violation of human rights, ${ }^{110}$ ISI also recognises the structural limitations of the human rights framework to addressing statelessness. ${ }^{111}$ In their two flagship reports on the world's stateless, ${ }^{112}$ working paper series, training courses and online toolkits, they make connections between statelessness and other international concerns, such as democracy, peace and security and development. ${ }^{113}$ Toward this end, the ISI is involved in global discussions around promoting a human rights-based approach to sustainable development, which is inclusive of the stateless. ${ }^{114}$

\section{Depoliticising StATELESSNESS to InTEGRATE IT IN GLOBAL}

\section{GOVERNANCE FRAMEWORKS}

As statelessness has been rediscovered as a phenomenon, global governance actors have been hard at work integrating the issue into emerging governance frameworks. The SDA, ${ }^{115}$ New York Declaration, ${ }^{116}$ the Global Compact on

104 Institute on Statelessness and Inclusion, 'What We Do'<http://www.institutesi.org/what-wedo>.

105 'Statelessness and Human Rights' (n 101).

106 Institute of Statelessness and Inclusion, The World's Stateless Children (Wolf Legal 2017).

107 Institute of Statelessness and Inclusion, 'About the CRC' <http://www.statelessnessandhumanrights.org/crc/about-the-crc> ('About the $C R C$ ').

108 European Network on Statelessness, '\#StatelessKids - None of Europe's Children Should Be Stateless' < https://www.statelessness.eu/statelesskids-no-child-should-be-stateless>.

109 'About the $C R C$ ' (n 107).

110 For their dedicated website on the issue, see Statelessness and Human Rights, 'Welcome' $<\mathrm{http}: / /$ www.statelessnessandhumanrights.org/>.

111 Institute of Statelessness and Inclusion, World's Stateless (n 7).

112 ibid; Institute of Statelessness and Inclusion, Stateless Children (n 106).

113 See e,g, Institute of Statelessness and Inclusion, 'Resources' $<$ http://www.institutesi.org/resources>.

114 Institute on Statelessness and Inclusion, Statelessness, Human Rights and the Sustainable Development Agenda (Working Paper, February 2017).

115 United Nations, 'The Sustainable Development Agenda' $<$ https://www.un.org/sustainabledevelopment/development-agenda/> accessed 27 May 2019.

116 New York Declaration for Refugees and Migrants, GA Res 71/1, UN Doc A/RES/71/1 (3 October 2016) ('New York Declaration'). 
Migration and the Global Compact on Refugees all mention statelessness. ${ }^{117}$ However, the ways in which it is incorporated provide further evidence of international organisations' depoliticisation of the issue as a strategy for making it an object of global governance. How an issue is framed has important consequences in terms of its uptake on the global governance agenda. Five years on from the watershed year of 2014, statelessness still enjoys only partial issue emergence, due in part to ongoing framing problems. As Lindsey Kingston's research indicates, statelessness is either placed into ready-made narratives about refugees or migrants, or narrowly defined as a legal issue wherein lack of legal nationality is seen as the most pressing concern for the stateless. ${ }^{118}$

In the $S D A$, several of the goals and targets are relevant to the elimination of statelessness and associated forms of discrimination. The most directly related target is SDG 16.9, which again frames the issue in rather narrow, technical terms: 'by 2030, provide legal identity for all, including birth registration' ${ }^{119}$ According to ISI, this may be open to interpretation and may not automatically guarantee the human right to a nationality. ${ }^{120}$ The target is worded in a way that acknowledges birth registration as an aspect of legal identity, but not its equivalent. ${ }^{121}$ Nonetheless, it is aligned with existing human rights obligations, and may make a positive contribution toward the prevention of child statelessness.

The UNHCR's technical framing of statelessness and institutional mandate are well represented in the New York Declaration, ${ }^{122}$ the Global Compact on Migration and the Global Compact on Refugees. ${ }^{123}$ The New York Declaration lays out commitments to address relevant governance challenges, including statelessness:

We recognize that statelessness can be a root cause of forced displacement and that forced displacement, in turn, can lead to statelessness. We take note of the campaign of the Office of the United Nations High Commissioner for Refugees to end statelessness within a decade and we encourage States to consider actions they could take to reduce the incidence of statelessness. We encourage those States that have not yet acceded to the 1954 Convention relating to the Status of Stateless Persons and the 1961 Convention on the Reduction of Statelessness to consider doing so. ${ }^{124}$

Here it is worth noting that whereas the focus of the document is on refugees and migrants, statelessness is framed exclusively in relation to UNHCR's mandate on forced displacement.

The New York Declaration also called for the development of global compacts on migration and refugees. ${ }^{125}$ The two processes were quite different in terms of

117 Global Compact for Safe, Orderly and Regular Migration (Compact, United Nations, 11 July 2018) ('Global Compact on Migration'); United Nations, The Global Compact on Refugees (Compact, 26 June 2018).

118 Lindsey N Kingston, 'Conceptualizing Statelessness as a Human Rights Challenge: Framing, Visual Representation, and (Partial) Issue Emergence' (2019) 11(1) Journal of Human Rights Practice 52.

119 Transforming Our World: The 2030 Agenda for Sustainable Development, GA Res 70/1, UN Doc A/RES/70/1 (25 September 2015) Goal 16.9.

120 Kingston (n 118).

121 Staples (n 82) 178.

122 New York Declaration (n 116) art 72.

123 Global Compact on Migration (n 117); The Global Compact on Refugees (n 117).

124 New York Declaration, UN Doc A/RES/71/1 (n 116) art 72.

125 ibid art 63, Annex I art 19, Annex II arts 1-2. 
procedure. The Global Compact for Safe, Orderly and Regular Migration was created through an extensive series of consultations and intergovernmental negotiations, led by the Special Representative for International Migration, Louise Arbour, and with prominent influence of the International Organization for Migration ('IOM'), which officially became a UN-related agency at the New York Summit in 2016. ${ }^{126}$ The final draft of the Global Compact on Migration was released in July 2018, and was adopted at an intergovernmental conference in Marrakech, Morocco in December 2018. 127

Consultation proceedings and notes from participant observation during this process suggest that the ongoing tension between neoliberal migration management and human-rights based approaches to migration governance continue to play out. Whereas the IOM approach emphasises safe and orderly migration in line with neoliberal concerns, OHCHR, International Labour Organization ('ILO'), UN Women and NGO coalitions came together in the first of six thematic sessions to discuss ' $[\mathrm{h}]$ uman rights of all migrants, social inclusion, cohesion, and all forms of discrimination, including racism, xenophobia and intolerance'. ${ }^{128}$ Child statelessness featured in the issue brief prepared for that session, as a specific need related to the human rights of migrants in vulnerable situations: 'For children born in a migratory context, there may be a risk of statelessness due to the additional hurdles they may face in establishing their nationality'. ${ }^{129}$ Yet again, the corresponding solution put forth in the co-chairs' summary report was narrow in focus, in line with UNHCR's action points: issue birth certificates to avoid statelessness.

Relevant language on ensuring all migrants have proof of legal identity and adequate documentation did make it into the final draft. This includes strengthening measures to reduce statelessness by registering migrants' births. ${ }^{130}$ At the same time, the final wording limits states' commitment to 'fulfil the right of all individuals to a legal identity by providing all our nationals with proof of nationality and relevant documentation'. ${ }^{131}$ During the intergovernmental negotiations on the zero draft of the compact, the Israeli delegation was observed to be leading a chorus of states pushing back against a clause calling for universal birth registration for migrants' children, claiming that their duty was only to nationals. ${ }^{132}$ While the Global Compact on Migration is an important complementary framework for protecting the right to a nationality, this kind of contradictory language may water it down considerably. Upholding a humanrights based approach, while also respecting state sovereignty has never been a straightforward task. As this paper suggests, some states continue to affirm the latter in order to shirk their responsibility for upholding the human right to a nationality.

126 United Nations 'Global Compact for Migration' < https://refugeesmigrants.un.org/migrationcompact>.

127 ibid.

128 Issue Brief 1: Human Rights of All Migrants, Social Inclusion, Cohesion and all Forms of Discrimination, Including Racism, Xenophobia and Intolerance (Brief, United Nations, May 2017).

129 ibid 5.

130 Global Compact on Migration (n 117) [20](e).

131 ibid [20].

132 Participant Observation Notes (International Migration Research Centre, New York, April 2018). 
The Global Compact on Refugees was proposed by UNHCR, building on the Comprehensive Refugee Response Framework already laid out in Annex I of the New York Declaration. ${ }^{133}$ Some consultations took place in 2017-18, mostly with state and non-state actors already collaborating with UNHCR in the implementation of the 'Comprehensive Refugee Response Framework' in pilot countries during this two-year period: national and local authorities, international organisations, international financial institutions, regional organisations, regional coordination and partnership mechanisms, civil society partners, including faithbased organisations and academia, the private sector, media and the refugees themselves. ${ }^{134}$ The final draft of the Global Compact on Refugees was also adopted in December 2018. ${ }^{135}$

Statelessness is mentioned in arts 60, 82 and 83 of the Global Compact on Refugees, ${ }^{136}$ with its usual emphasis on identification, birth registration and documentation. Importantly, art 82 distinguishes between birth registration and the conferral of a nationality: 'while it does not necessarily lead to conferral of nationality, birth registration helps establish legal identity and prevent the risk of statelessness'. 137 This emphasis suggests the Global Compact for Refugees is likely to reaffirm UNHCR's existing technical approach to statelessness prevention and reduction, though the call for establishing a global academic network on refugee and statelessness issues (art 43) represents an important move toward ongoing dialogue on these issues.

\section{Concluding Remarks: SEEING THE STATE In STATELESSNESS AND NEW}

\section{WAYS OF SEEING}

This paper has endeavoured to contrast the slippery statecraft involved in governments' strategic use of citizenship to govern human mobility, with global governance actors' tendency to turn statelessness into a non-political problem in need of technical solutions. Since 2013, statelessness has been rediscovered as an egregious violation of human rights and pressing challenge to global governance. Yet the framing of the issue by UNHCR and other global governance actors continues to assume that statelessness can be resolved - provided there is political will - within the existing international system of states and human rights framework through relatively simple reforms. Contrasting the messy politics involved in creating contemporary situations of statelessness, as opposed to its narrow technical and legalistic framing, reveals a tendency toward depoliticisation of what is a fundamentally political problem.

Comparing the broader structural causes of statelessness with UNHCR's Global Action Plan raises important concerns regarding the ethics and efficacy of their campaign to end statelessness. The post-9/11 securitisation of citizenship poses ethical questions regarding the potentially discriminatory effects of biometric technologies. UNHCR's emphasis on birth registration and identity documentation, which are often produced using these new technologies, has been criticised as problematic and potentially exacerbating state-sponsored

133 New York Declaration (n 116) Annex I.

134 United Nations High Commissioner for Refugees, 'Formal Consultations' $<$ https://www.unhcr.org/formal-consultations-on-the-global-compact-on-refugees.html $>$.

135 The Global Compact on Refugees (n 117).

136 ibid [60], [82], [83].

137 ibid. 
discrimination. 138 The central problem of UNHCR's mode of intervention, argues Kelly Staples, is that it ignores the politics of recognition and the 'state part of statelessness'. ${ }^{139}$ UNHCR's insistence on determining the place where a particular group belongs, despite a state's unwillingness to recognise them, may actually put the group they are seeking to protect at risk. Staples cites the example of UNHCR's repatriation of stateless Rohingya to Myanmar between 1992 and 1995, which has had devastating consequences. ${ }^{140}$ To this, I might add the example of UNHCR's biometric identification and creation of a database not only of the Rohingya in camps in Bangladesh, but also of thousands of stateless Dominicans of Haitian descent, which the agency plans to deliver to the Dominican government as proof of the existence of statelessness in country. ${ }^{141}$ No solution has been negotiated for their recognition as nationals, and the lack of political will is abundantly clear. Making legible a population which a given state is unwilling to recognise is not only ineffectual; it is unethical.

International human rights law has been a fundamental tool for curbing states' use and abuse of sovereign power. Yet the human rights framework may not be enough to eliminate statelessness since, as we have seen, the ability to access human rights hinges on state recognition. Hannah Arendt, too, suggested that a lesson of the twentieth century was the fallacy and naivete of believing that human rights can be defended by legal means alone. ${ }^{142}$ Yet, the UNHCR Global Action Plan, ISI and the Global Campaign for Equal Nationality Rights place much emphasis on the relationship between nationality law and statelessness, when in fact other factors are at play, such as weak institutions, poor infrastructure, conflict, political instability and of course, discrimination. ${ }^{143}$ Perhaps most problematic is the assumption that discrimination on the basis of race or gender, as a causal factor of statelessness, can be eliminated primarily through legislative reform.

Doubtful, too, is the assertion that states can end statelessness. Critical scholarship on statelessness suggests that it is not only a phenomenon, but endemic to the very structure of the international state system. ${ }^{144}$ Seeing persons without a state affirms the rather obvious: the modern sovereign state constitutes its citizenry, and not the other way around. ${ }^{145}$ Manipulation of citizenship is similar to states 'making people illegal' 146 or what Anne McNevin refers to as the vicious cycle between border control and irregular migration. ${ }^{147}$ Sovereign states wield citizenship as an instrument of governance, fundamental to their interpretation of rights obligations and also to the regulation of movement between states. Some

\footnotetext{
138 Staples (n 82) 178-80.

139 ibid 173.

140 ibid 175.

141 This is based on the author's fieldnotes from research in the Dominican Republic, 2015-17.

142 Serena Parekh, Hannah Arendt and the Challenge of Modernity: A Phenomenology of Human Rights (Routledge 2008) 50.

143 Staples (n 82) 182.

144 Bloom, Tonkiss and Cole (n 25) 4-5; Patrick Hayden, 'From Exclusion to Containment: Arendt, Sovereign Power, and Statelessness" (2008) 3(2) Societies Without Borders 248, 267.

145 Monika Krause, 'Undocumented Migrants: an Arendtian perspective' (2008) 7(3) European Journal of Political Theory 331, 338.

146 Catherine Dauvergne, Making People Illegal: What Globalization Means for Migration and the Law (Cambridge University Press 2008).

147 Anne McNevin, 'Learning to Live With Irregular Migration: Towards a More Ambitious
} Debate on the Politics of "the Problem"” (2017) 21(3) Citizenship Studies 255, 255. 
have argued that the international order itself depends on citizenship. ${ }^{148}$ If statelessness is indeed a product of slippery statecraft, then I suggest it cannot be resolved unless advocates and scholars stop 'seeing like a state' 149 and start seeing the state in statelessness.

So what is at stake for global governance? Does this make the issue of statelessness intractable? What becomes increasingly clear are the limits of the nation-state framework to deliver justice. As Nancy Fraser points out, the Westphalian view is that justice applies within the territory of a nation-state to citizen subjects, which frames first-order questions of justice unjustly. ${ }^{150}$ The sovereign state draws the frame as it will, inevitably but arguably avoidably, casting unwanted 'others' outside the frame. Boundaries of inclusion/exclusion are worrisome matters from a perspective of justice and human rights for any number of groups that have been othered. When a collective finds itself outside of all state boundaries, yet still needing to reside somewhere on the planet, their very existence challenges the international system of nation-states and its carving up of international space. Our earlier analysis of the causes of statelessness reveals how multiple forms of social exclusion converge to produce the ultimate exclusion: the person who, politically, does not belong anywhere on earth.

This suggests a different frame from which to consider justice for the stateless: belonging. UNHCR alludes to this in its campaign title, '\#IBELONG' yet proposed solutions are circumscribed by statist assumptions. ${ }^{151}$ One of the primary injustices facing the stateless, Matthew Gibney aptly points out, 152 is not that they cannot find a state to call home, but rather that the state to which they arguably belong and which should recognise them as citizens refuses to do so. On the other hand, some stateless groups, such as Palestinians, may feel they already belong to a national group; in their case, maintaining a stateless status may form part of an ongoing political claim for statehood notwithstanding their exclusion from the Refugee Convention and UNHCR mandate for protection of refugees and the stateless. ${ }^{153}$

To move beyond such an impasse, political theorist Kristy Belton argues for the 'right to belong' using a framework of global distributive justice in which citizenship is seen as a good subject to fair distribution. ${ }^{154}$ Belton's proposal of just membership for stateless people moves beyond statist practices of inclusion and exclusion by granting agency to stateless individuals to determine where it is they wish to belong. ${ }^{155}$ Such a proposition would imply the creation and recognition of new and more specific rights than the right to $a$ nationality, such as

148 Barry Hindess, 'Citizenship and Empire' in Thomas Blom Hansen and Finn Stepputat (eds), Sovereign Bodies: Citizens, Migrants, and States in the Postcolonial World (Princeton University Press 2005) 241, 256.

149 James C Scott, Seeing Like a State: How Certain Schemes to Improve the Human Condition Have Failed (Yale University Press 1999).

150 Fraser (n 14) 294.

151 United Nations High Commissioner for Refugees, ‘\#IBelong Campaign to End Statelessness' $<$ https://www.unhcr.org/ibelong-campaign-to-end-statelessness.html $>$.

152 Matthew Gibney, 'Statelessness and the Right to Citizenship' (2009) 32 Forced Migration Review 50-51.

153 Maissaa Almustafa, 'Relieved Vulnerabilities of Palestinian Refugees: Governing Through Exclusion' (2017) 27(4) Social and Legal Studies 164.

154 Belton (n 13) 165.

155 ibid 175. 
the human right to membership, ${ }^{156}$ the right to political membership, ${ }^{157}$ or the right to naturalise. ${ }^{158}$ According to Belton's formulation,

each stateless person has the right to the good of citizenship in the state of his or her birth from the moment he or she is born or to the right of citizenship in the state where he or she has made a life via residence. ${ }^{159}$

Bringing the politics of statelessness back in, belonging here is better understood as 'a negotiated and dynamic institution'. ${ }^{160}$ With whom will the stateless negotiate, if outside the Westphalian frame of justice? Since negotiation with a state that negates one's existence may prove difficult, new cosmopolitan formulations of law and sovereignty ${ }^{161}$ are needed to submit exclusionary national sovereignties to overarching principles of justice and novel interpretations of who belongs. Perhaps only then can brave new citizenries craft the states to which they have the political will to belong, and not the other way around.

156 Seyla Benhabib, The Rights of Others: Aliens, Residents and Citizens (Cambridge University Press 2004) 141.

157 William A Barbieri Jr, Ethics of Citizenship: Immigration and Group Rights in Germany (Duke University Press 1998) 115.

158 Benhabib (n 156).

159 Belton (n 13) 177.

160 Engin F Isin and Peter Nyers (eds), Routledge Handbook of Global Citizenship Studies (Routledge 2014) 2.

161 Held 'Three Models of Sovereignty' (n 20). 